\title{
Soccer, stock returns and fanaticism: Evidence from Turkey
}

\author{
M. Hakan Berument ${ }^{\mathrm{a}, *}$, Nildag Basak Ceylan ${ }^{\mathrm{b}}$, Gulin Ogut-Eker $^{\mathrm{c}}$ \\ a Department of Economics, Bilkent University, Ankara, Turkey \\ ${ }^{\mathrm{b}}$ Department of Management, Atilim University, Ankara, Turkey \\ ${ }^{c}$ Department of Turkish Language and Literature, Hacettepe University, Ankara, Turkey
}

\begin{abstract}
This paper assesses the effect of three major soccer teams' wins on the returns of the Istanbul Stock Exchange (ISE). We argue that the effect of soccer wins on ISE returns increases with the fanaticism of the teams' supporters.

(C) 2009 Western Social Science Association. Published by Elsevier Inc. All rights reserved.
\end{abstract}

\section{Introduction}

This paper reports the estimates of an empirical exercise that ties the success of Turkey's three major soccer ${ }^{1}$ teams (Beşiktaş, Fenerbahçe and Galatasaray), each having a more or less equal number of fans across the country, to stock market returns by using the daily data from Turkey from July 3, 1987 to November 10, 2006. The hypothesis that we tested in this paper is whether the returns on the Istanbul Stock Exchange (ISE) can be associated with the wins of teams and the strength of the emotional ties that supporters who happen to be brokers/traders have to their teams. To be specific, we are concerned with three questions: (i) Are the wins of the three soccer teams associated with higher returns? (ii) Are the returns different, depending on which team won? (iii) Are these returns tied to the fanaticism of the fans of these three teams?

In behavioral finance, emotional and visceral factors are often considered important determinants of asset pricing (see Stracca, 2004). When faced with uncertainty, agents who make decisions weigh their objective probabilities subjectively. Thus, as discussed by Loewenstein (2000), Loewenstein, Weber, Hsee, and Welch (2001), and Romer (2000), the probability weighting function depends on the agent's emotional state. Therefore, asset prices are affected by the state of the agent's emotions.

* Corresponding author. Tel.: +90 312290 2342; fax: +90 3122665140.

E-mail address: berument@ bilkent.edu.tr (M.H. Berument). 
Society attaches importance to the successes and failures of major sports teams. The supporters of a soccer team feel proud and happy when their team wins and they feel depressed and unhappy when their team loses. Thus, any investment decisions a fan makes may be affected by on the performance of his or her team. It has been reported that a good result in soccer affects a trader's moods or psychological well-being. Ashton, Gerrard, and Hudson (2003), Boyle and Walter (2003), and Whitfield (2003) argue that buoyed brokers behave bullishly, and Edmans, Garcia, and Norli (2007) point out that daily stock returns decrease after losses in World Cup elimination matches. Using Turkish data, Berument, Ceylan, and Gozpinar (2006) similarly argue that stock market returns increase with wins. However, association with a team's success varies between fans. The degree of fanaticism increases the association. Grove, Hanrahan, and McInman (1991), Wann and Branscombe (1993), and Wann and Dolan (1994) suggest that fans with high team identification levels have a tendency to internalize their team's attributes after their team's wins, which, being an ego-enhancer, increases their self-esteem. Thus, the degree of team identification/fanaticism matters for the effect of soccer matches on stock market returns.

In this study, similar to those of Ashton et al. (2003), Boyle and Walter (2003), Edmans et al. (2007), and Berument et al. (2006), the trader's psychological well-being is proxied with the sports teams' international match results. However, the contribution of this paper is to assess whether the effect of the teams' wins on the stock market is a function of fanaticism and to determine whether the degree of effect depends on the degree of fanaticism of the fans.

Using data from Turkey has various advantages. First, Beşiktaş, Fenerbahçe, and Galatasaray have supporters all around the country rather than being concentrated in one geographic region, which allows us to observe the effects of success on the whole country rather than on a small area. Second, most Turks associate themselves with one of these three major teams (even if they are also supporters of a local team). In Turkey, to the public and media alike, soccer is generally viewed as the most important sport (see Berument and Yucel, 2005, for further elaboration on soccer in Turkey). The above factors make Turkey a good laboratory in which to assess the effects of soccer on economic/financial variables.

\section{Method}

\subsection{Data}

The data consist of a daily closing stock market index, the exchange rates and the international soccer results of the three major Turkish soccer teams from July 3, 1987 to November 10,2006 . There are various reasons for only including the teams' international matches in the sample. First of all, in a domestic game, one team's win means the other team's loss, and thus their effects on the ISE may cancel each other out. Second, the success of a team in a domestic league increases its fans' morale and decreases the morale of the other team's fans. In contrast, when a Turkish team plays against a foreign rival, even the domestic non-fans of the team are assumed to support the Turkish team. Thus, the country's morale as a whole increases when a domestic team wins against a foreign rival.

Turkey has had a high and volatile inflation rate, so agents evaluate the daily performance of its stock market by looking at its USD value; the USD value is the most widely followed 
indicator of the state of the ISE. The stock market return $\left(\right.$ Return $\left._{t}\right)$ is calculated by the logarithmic first difference of the USD value of the stock market price index gathered from the EVDS data delivery system of the Central Bank of the Republic of Turkey. The returns are calculated as follows:

$$
\text { Return }_{t}=\left[\log \left(\frac{I S E 100_{t}}{I S E 100_{t-1}}\right)-\log \left(\frac{U S D_{t}}{U S D_{t-1}}\right)\right] \times 100
$$

where ISE 100 is the daily closing price of the ISE 100 index and USD is the Turkish lira value of the USD. ${ }^{2}$

\subsection{Method}

In order to model the return, we use transfer function analysis. Therefore, we assume that return follows an autoregressive path: we regress the return on its lags up to the second order. ${ }^{3}$ Then, five dummy variables are included to account for the day-of-the-week effect. The success variables of the three soccer teams are incorporated with the value of one if a team wins against a foreign rival and zero otherwise. It should be noted that the dummy variables are assigned as an observation for the next business day due to the fact that the majority of the games are played outside the operating hours of the Istanbul Stock Exchange. Thus, our equation can be denoted as follows:

$$
\operatorname{Return}_{t}=\sum_{i=1}^{5} \alpha_{i} D_{i, t}+\sum_{j=1}^{2} \beta_{j} \operatorname{Return}_{t-j}+\eta \operatorname{win}_{t}+\varepsilon_{t}
$$

where $D_{1, t}, D_{2, t}, D_{3, t}, D_{4, t}$, and $D_{5, t}$ are the five dummy variables for each day and win is the dummy variable for the success of three teams. The international soccer results of Beşiktaş, Fenerbahçe, and Galatasaray are gathered from Durupınar (2002), Tanrıkulu (2002), and Tuncay (2001). The soccer results are updated from www.rsssf.org, the daily Turkish newspapers http://www.radikal.com and http://www.hurriyet.com.tr, and from İbrahim Kırkayak of TRT Sports Service.

\section{Results and discussion}

The table reports the estimates of our basic specification. Here $\operatorname{win}_{t}$ is the summation of the win scores of Beşiktaş, Fenerbahçe, and Galatasaray against their foreign rivals. Monday, Tuesday, Wednesday, Thursday, and Friday are the dummy variables that take the day-ofthe-week effect into consideration. Return ${ }_{t-1}$ and Return $_{t-2}$ are the estimated coefficients for the first two lags of return. Note that the estimated coefficient for the win variable is 0.151 . This suggests that once the day-of-the-week effect and the dynamics of the lagged returns are accounted for, stock market returns increase by $0.151 \%$. This supports the proposition that wins are associated with higher returns. Although the magnitude is positive, it is not statistically significant. $^{4}$ 
Our results parallel the findings of Ashton et al. (2003), Boyle and Walter (2003), Berument et al. (2006), and Edmans et al. (2007). Berument et al. (2006) analyze the effect of soccer success on stock market returns for the three major Turkish teams; their findings suggests that Beşiktaş's win against a foreign rival in the Winner's Cup increased stock market returns. That result is in line with the results of our study. In our study, however, the wins are associated with fanaticism, which gives our results a different slant. Ashton et al. (2003) apply eventstudy analysis to test index movements on the London Stock Exchange following international matches by the British national soccer team. The results show that the performance of the British team is significantly associated with the next trading day's stock market returns; similar to our study, wins are associated with positive returns and losses with negative returns. Ashton's study differs from our study in that they report findings for only the British national soccer team, not for individual soccer teams. While they report that the influence on the stock market increases after relatively more important tournament matches, they did not considered the effect of fanaticism. Boyle and Walter (2003) analyze the effects of success of the New Zealand national rugby team on stock market returns, and report that they could not find any evidence that a relationship between sporting team success and stock market return behavior exists. (These results contrast our findings.) As with the study on the British team, and dissimilar to our study, the results of only the national team's rugby matches are considered and fanaticism is not assessed. Similar to our work, Edmans et al. (2007) investigate the effect of sudden changes in investor mood on the stock market using international soccer results and they find a significant market decline after soccer losses for 39 countries. Different from our study, their work also investigates the impact of cricket, rugby, ice hockey, and basketball results and they considered only the losses. ${ }^{5}$

As we elaborated on earlier, not all a team's fans associate their team's success with their own success. Ögüut-Eker (2006) notes that not all fans of Turkey's three big teams have the same level of fanaticism. She argues that, based on the intensity of their cheering, police reports regarding crime rates before matches, and questionnaires that soccer fans filled out, supporters of Beşiktaş have the highest degree of fanaticism and Galatasaray fans have the lowest. Salman (2005)'s survey also reveal Beşiktaş to have the most fanatic supporters of the big three Turkish teams. According to Salman, Beşiktaş fans (i) most often attend matches and are the most knowledgeable about their team; (ii) hang the flag of their team after the matches most often; (iii) mostly answered affirmed the statement "I tour with my car after the important matches won by my team" ( $41.4 \%$ of Beiktaş fans tour after an important win); and (iv) are most likely to choose the colors of their belongings based on the colors of their team (by 56.6\%). A report from the Turkish Police Force ranks Beşiktaş as the team with the highest degree of fanatic supporters (Beşiktaş is the most fanatic (2009)).

Column 2 of Table 1 reports the estimates when the successes of these three teams enter into the specification individually. Note that only the estimated coefficient for Beşiktaş is positive and statistically significant, while the coefficients for Fenerbahçe and Galatasaray are not statistically significant. This supports the proposition that the degree of fanaticism around wins affects stock market returns, with a higher degree of fanaticism increasing the responses of ISE returns. ${ }^{6}$ In order to better observe this effect we want to quantify it. To be specific, Beşiktaş' last foreign win in our sample was on September 14, 2006 and the value of the stock market was approximately 150 billion USD (220 billion YTL). Its value increased the next 
Table 1

Returns and successes in soccer.

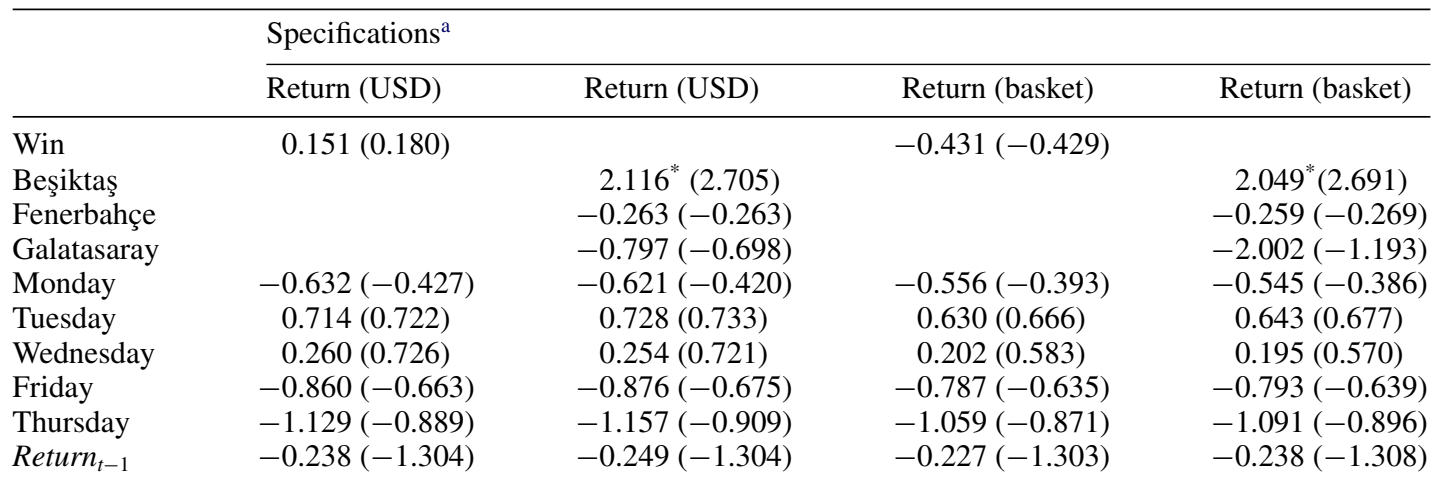

\begin{tabular}{|c|c|c|c|c|}
\hline & \multicolumn{4}{|l|}{ Specifications } \\
\hline & Return (USD) & Return (USD) & Return (basket) & Return (basket) \\
\hline Return $_{t-2}$ & $-0.247(-1.349)$ & $-0.257(-1.349)$ & $-0.235(-1.349)$ & $-0.246(-1.352)$ \\
\hline$R^{2}$ & 0.094 & 0.093 & 0.094 & 0.094 \\
\hline SSR & 6058480.183 & 6060940.879 & 5540914.947 & 5539375.335 \\
\hline DW & 2.049 & 2.050 & 2.045 & 2.044 \\
\hline
\end{tabular}

${ }^{a} t$-statistics are reported in parentheses under the corresponding estimated parameters. $(*)$ denotes significance at the $1 \%$ level.

business day by close to three billion USD (four billion YTL). On September 15, 2006, the value of Beşiktaş was 81.9 million USD (120.8 million YTL) and its value increased by 1.28 million USD (1.6 million YTL) from its September 14, 2006 value.

Turkey is a small open economy, so the TL value of the official basket (1 USD + 0.77 Euro) is used for the operations of the Central Bank of Turkey (rather than the TL value of the USD). Therefore, we repeat the exercise with the ISE 100 index deflated by the basket, and the estimates are reported in columns 3 and 4 . The results are robust.

\section{Conclusion}

In this paper, we examined how soccer success affects stock market returns for the three major Turkish soccer teams. To this end, we assess the effects of the teams' wins on stock market returns. The wins can be considered a function of fanaticism and tested as to whether the degree of effect of wins in soccer matches on stock market returns depends on the degree of fanaticism of sports fans. The results are in line with the proposition that wins are associated with higher returns. Moreover, when the teams' performances assessed individually, the findings show that stock market returns increased following Beşiktaş's (whose fans have a high rate of fanaticism) wins against foreign rivals. No similar effect is reported for Fenerbahçe and Galatasaray, whose supporters have lower rates of fanaticism. We tie this statistically significant evidence regarding the Beşiktaş's win to its supporters' higher degree of fanaticism. 


\section{Notes}

1. The name of the sport is football in some countries, and in Canada and the United States, it is soccer. In Australia, Ireland, Japan, New Zealand, and South Africa both words are commonly used.

2. Taylor and Tonks (1989) have also deflated various price index series using exchange rates. The US Standard and Poor's Composite Index, and the Japanese Tokyo New Stock Exchange Index were deflated by the UK Sterling exchange rate.

3. The lag order is determined by Bayesian Information Criteria.

4. The level of significance is $5 \%$ unless otherwise stated.

5. As a separate exercise, not reported here to save space, we also consider losses rather than wins. The statistical evidence was not significant for any team that we consider in this paper.

6. One could argue that it is not the degree of fanaticism but the number of supporters that might be the reason for Beşiktaş's effect on the ISE. Although there are no official or reliable statistics available in Turkey regarding the number of fans of these three big teams, by observing the common media news, we can safely assume that their numbers are fairly equal.

\section{Acknowledgements}

We would like to thank Ibrahim Kirkayak, Rana Nelson and two anonymous referees for their valuable comments.

\section{References}

Ashton, J., Gerrard, B., \& Hudson, R. (2003). Economic impact of national sporting success: Evidence from the London Stock Exchange. Applied Economic Letters, 10, 783-785.

Berument, H., Ceylan, N. B., \& Gozpinar, E. (2006). Performance of soccer on the stock market: Evidence from Turkey. The Social Science Journal, 43, 695-699.

Berument, H., \& Yucel, E. (2005). Long live Fenerbahçe: Production boosting effects of soccer in Turkey. Journal of Economic Psychology, 26, 842-861.

Beşiktaş, is the most fanatic (in Turkish), (2009, January 3). Hurriyet, p. 23.

Boyle, G., \& Walter, B. (2003). Reflected glory and failure: International sporting success and the stock market. Applied Financial Economics, 13, 225-235.

Durupınar, M. (2002). History of Beşiktaş with its legends, heroes and numbers (in Turkish). Istanbul: Yapi Kredi Cultural Press.

Edmans, A., Garcia, D., \& Norli, Ø. (2007). Sports sentiment and stock returns. Journal of Finance, 62, 1967-1998.

Grove, J. R., Hanrahan, S. J., \& McInman, A. D. (1991). Success/failure bias in attributions across involvement categories in sport. Personality and Social Psychology Bulletin, 17, 93-97.

Loewenstein, G. (2000). Emotions in economic theory and economic behavior. American Economic Review, 90(2), 426-432.

Loewenstein, G. F., Weber, E. U., Hsee, C. K., \& Welch, N. (2001). Risk as feelings. Psychological Bulletin, 127(2), 267-286. 
Öğ̈̈t-Eker, G. (2006). The Irresistable Attractiveness of Soccer and a Magnetized Supporter Portrait (in Turkish). Unpublished manuscript.

Romer, P. M. (2000). Thinking and feeling. American Economic Review, 90(2), 439-443.

Salman, G. G. (2005). Why do We Support Teams? (in Turkish). Bahçeşehir University, Faculty of Management Working paper.

Stracca, L. (2004). Behavioral finance and asset prices: Where do we stand? Journal of Economic Psychology, 25(3), 373-405.

Tanrıkulu, A. (2002). History of Fenerbahçe with its legends, heroes and numbers (in Turkish). Istanbul: Yapi Kredi Cultural Press.

Taylor, M., \& Tonks, I. (1989). The internationalization of stock markets and the abolition of U.K. exchange control. The Review of Economics and Statistics, 71, 332-336.

Tuncay, B. (2001). History of Galatasaray with its legends, heroes and numbers (in Turkish). Istanbul: Yapi Kredi Cultural Press.

Wann, D., \& Branscombe, N. (1993). Sports fans: Measuring degree of identification with their team. International Journal of Sport Psychology, 24, 1-17.

Wann, D. L., \& Dolan, T. J. (1994). Attributions of highly identified sports spectators. Journal of Social Psychology, 134(6), 783-794.

Whitfield, J. (2003, November 13). Football results kick share prices. Nature, 